\title{
Analysis of Public Accounting Systems in the European Union
}

\author{
Sabrina Bellanca ${ }^{1}$, Loredana Cultrera ${ }^{1} \&$ Guillaume Vermeylen ${ }^{1}$ \\ ${ }^{1}$ Warocqué School of Business and Economics, University of Mons, Mons, Belgium \\ Correspondence: Loredana Cultrera, Warocqué School of Business and Economics, University of Mons, Place \\ Warocqué 17 - 7000 Mons, Belgium. Tel: 32-65-373-253
}

Received: August 10, 2015

Accepted: August 28, 2015

Online Published: September 1, 2015

doi:10.5430/rwe.v6n3p23

URL: http://dx.doi.org/10.5430/rwe.v6n3p23

\begin{abstract}
Public accounting is continuously evolving and accrual accounting gains importance in governments. As a part of the New Public Management, this concept applies the practices used in the private sector to the public sector. The application of new accounting methods improves financial management and decision making. The European Union, through its Directive 2011/85/EU of November 8, 2011, is really sensitive to the use of reliable and transparent accounting data and accrual accounting could be a very interesting tool to provide quality data.

So, the aim of this paper is to analyze the accounting systems used in the European Union Member States. After a review of the literature including concepts of New Public Management and accrual accounting, we classify, on the basis of a survey carried out in the European Union Member States, the States according to the accounting system they use at the central level and at the local level. This system can be cash basis accounting, modified cash basis accounting, accrual accounting or modified accrual accounting. We conclude that there are important disparities between the Member States and also within the country from a government level to another. However, we can see that accrual accounting is dominant in the European Union Member States.
\end{abstract}

Keywords: public accounting, new public management, accounting reform, European survey

\section{Introduction}

Accrual accounting has become the reference of accounting systems for public sector entities. This concept is a part of the New Public Management, whose main objective is to bring closer the practices of public and private management. Thus, by focusing on efficiency and effectiveness, the new public management involves using new methods of accounting that improve financial management and decision making, and thus make more efficient and competitive public policies and governments more responsible.

The European Union, especially through its Directive 2011/85/EU of November 8, 2011 on requirements for budgetary frameworks of the Member States, underlines the importance to its member countries, to have reliable and transparent data. It states that exhaustive and reliable public accounting practices are essential for producing consistent and high-quality statistics. Thus, it seems that accrual accounting is a very interesting tool to meet this need.

This article offers a representative picture of the accounting methods used within member countries of the European Union, and this, at central and local government levels. Firstly, the paper presents the concept of New Public Management, its origin and its implications for the government. The literature review also tackles the concept of accrual accounting and discusses the European legislation on requirements for budgetary frameworks of the Member States. The methodology and results of our survey are then presented. We conducted a questionnaire survey sent to the different member countries of the European Union in order to know which type of accounting is used in each country. We asked them to choose between cash accounting, modified cash accounting, accrual accounting and modified accrual accounting, to best describe the accounting system used at central and local levels.

It brings out from our investigation that the government accounting systems are heterogeneous between the different States but also within a State. Indeed, while Belgium, Estonia, France, Lithuania, Portugal, Romania, the United Kingdom, Slovakia and Sweden, are using an accrual accounting exercise for all the government levels, others are still working on a cash accounting, as it's the case for Italy for example. However, we conclude the prevalence of the accrual accounting on cash accounting in the European Union. 


\section{New Public Management: Introduction to Accrual Accounting}

Traditionally, public accounting is a cash budget accounting. Invented 250 years ago in Austria and first developed in Austria, Belgium, Finland and Germany (Note 1), this system doesn't allow recording some economic events and, therefore, doesn't provide information about wealth management and debt (Lüders \& Jones, 2003). But in recent years, the development of accrual accounting and general financial accounting, as part of a broader framework of the New Public Management, has been observed in various countries, especially countries from the European Union.

New Public Management that appeared in the late 70s in the United Kingdom and the United States (Note 2), aims to improve public sector practices to make public administrations more competitive and more responsible, following the example of the best private companies.

This is the logic of a market turning, among others things, on flexibility, efficiency and effectiveness (Pina \& Torres, 2003) and which has been developed especially to solve the problems of over indebtedness, significant deficit and public sector inefficiency of the States (Amar \& Berthier, 2008). New Public Management introduces new methods of management, focused on results rather than on process and stressing on efficiency and transparency. This new way of considering public management materializes itself by a set of reforms that bring public entities to develop new ways of working, particularly in terms of accounting, since one of the key elements of the New Public Management is the replacement of the traditional cash accounting to an accrual accounting based on transactions, allowing, among other things, the identification of assets, liabilities, incomes and expenses (Note 3). Accrual accounting is to record financial transactions when they occur and not when payment is made as is the case in cash accounting. Thus, accrual accounting should facilitate planning, financial management and decision-making in governments and, in this manner, to lead to public policies more effective.

This "new" public accounting has been adopted by the European Commission in 2005 to elaborate its own financial statements and several countries in Europe and from the globe have implemented reforms to modernize their accounting (in Mawhood Baumann, 2008).

The directive 2011/85/EU of November 8, 2011 on requirements for budgetary frameworks of the Member States underlines, among others things, the importance of the availability of fiscal data (prepared according to the principles of the European System of Accounts or ESA) that must be updated and reliable in order to ensure transparency and proper functioning of the budgetary surveillance framework of the European Union. This transparency and reliability are essential to the achievement of macroeconomic and budgetary realistic forecasts, while respecting budgetary discipline imposed on Member States by the Treaty on the Functioning of the European Union (TFEU). The directive specifies that "the application of exhaustive and reliable public accounting practices in all sub-sectors of general governments is a prerequisite for the production of high quality statistics that are comparable from one State member to another". Thus, accrual accounting seems to respond to this need for transparency and reliability in the public sector, since it provides a multitude of information and provides a solid foundation for financial analysis.

In Europe (and worldwide), the public accounting systems differ from one country to another and within the same country, from a level of power to another. Thus, we notice some heterogeneity rules and accounting "reporting". We could classify public accounting systems into two broad categories, that is "Anglo-Saxon" accounting systems and "continental" accounting systems (Pina \& Torres, 2003; Torres, 2004). The first category, which can be associated with the United Kingdom in Europe and Australia, New Zealand, the United States and Canada, on a global scale, is an approach to accounting based on the private model, which focuses on efficiency and effectiveness. Therefore, the accounting system adopted provides more accurate information, influenced by the rules into effect in the private sector. The "continental" approach, meanwhile, is less influenced by the practices of the private sector and the budget remains the dominant tool of the accounting system. This culture is unique to Belgium, France, Germany, Greece, Portugal, Spain, Italy and Switzerland. In addition, a Nordic tradition would also be present and would constitute a hybrid form of the "continental" approach and of the "Anglo-Saxon" approach. It would include countries such as Denmark, Finland, Sweden and the Netherlands.

Public accounting is constantly changing and accrual accounting occupies currently an important place in the political debate on the consistency, transparency and reliability of accounting data. Thus, how do the accounting systems of the Member States of the EU have evolved? Is accrual accounting fully utilized in these different countries? We try in this article to answer these questions.

\section{Methodology}

In this article, we focused ourselves on the accounting systems currently used by different member countries of the European Union. In this objective, we sent in 2012 and 2013, mainly electronically, a questionnaire to different 
authorities in the field (mainly the Ministry of Finance) and various scientists working on the field of accounting (public) and this, for each member country. We now have received 31 responses (corresponding to 23 countries).

The purpose of the questionnaire was to determine the type of accounting that was actually used in each country (local and central levels). We proposed, for each question, several answers and that is, for the sake of consistency and harmonization of the results.

We offered to the respondents the opportunity to choose among the following systems, the one that best describes the system being used (the question was asked to the local level and the central level):

- Cash accounting: method that records transactions and other events when cash is received or paid;

- Modified cash accounting: a hybrid method that takes into account, for the most part, the cash accounting, but that also takes into account unpaid accounts and /or accounts receivables at the end of the year;

- Accrual accounting: method by which transactions and other events are recorded when they occur and not only in case of receipt or disbursement;

- Modified accrual accounting: method that tends to full accrual accounting but with some differences, including the non-consideration of some classes of asset or liability.

If the accounting used in public entities didn't match any of the methods described above, it was asked to choose the nearest type of accounting system and precise the differences with the accounting system currently used.

\section{Results}

Our survey reveals the following results:

Table 1. Accounting system used at a central level by Member States of the European Union

\begin{tabular}{|c|c|}
\hline$\frac{\text { Accounting system currently used at a central }}{\underline{\text { level }}}$ & $\underline{\text { Countries }}$ \\
\hline Cash accounting & Italy \\
\hline Modified cash accounting & $\begin{array}{l}\text { Germany, Bulgaria, Spain, Finland, Greece, Hungary, } \\
\text { Italy, Malta, Netherlands, Portugal, Slovenia }\end{array}$ \\
\hline Accrual accounting & $\begin{array}{l}\text { Austria (from 2013), Belgium, Estonia, France, } \\
\text { Lithuania, Portugal, United Kingdom, Slovakia, Sweden }\end{array}$ \\
\hline Modified accrual accounting & $\begin{array}{c}\text { Austria (until December 31, 2012), Belgium, Latvia, } \\
\text { Czech Republic, Romania }\end{array}$ \\
\hline
\end{tabular}

Table 2. Accounting system used at a local level by Member States of the European Union

\begin{tabular}{cc}
\hline Accounting system currently used at central level & Countries \\
\hline Cash accounting & Bulgaria, Italy \\
\hline Modified cash accounting & Austria, Spain, Hungary, Portugal \\
\hline Accrual accounting & $\begin{array}{c}\text { Germany (Note 4), Belgium, Estonia, France, Greece, } \\
\text { Lithuania, Malta, Netherlands, Portugal, United } \\
\text { Kingdom, Slovakia, Sweden }\end{array}$ \\
\hline Modified cash accounting & Belgium, Finland, Latvia, Czech Republic, Romania, \\
Slovenia
\end{tabular}


There is to note that some states are repeatedly mentioned in the tables. This is due to the uncertainty of the respondents to our survey about their positioning.

According to the literature, we find some inter (and intra) national heterogeneity of accounting systems.

\section{Germany}

The German federal structure is as follows: Federation, Länder and municipalities. The budget process of the Federation and Länder is based on revenues and expenses and is founded on the provisions of the Fundamental Law for the Federal Republic of Germany (art. 109-115) as well as the Law on Budgetary Principles ("Haushaltsgrundsätzegesets" or "HGrG"). According to this law, public accounting can follow a cash or accrual accounting. According to our survey, the public accounting system at the central level consists of two components: a budget accounting based on commitments and a rudimentary financial accounting. On the other hand, at the local level each Länder have the power to regulate the accounting system for the municipalities that are on its territory. Therefore, accounting practices differ from one Land to another. Thus, while some Länder have decided to adopt accrual accounting, others prefer to maintain a cash accounting. However, although most $L a ̈ n d e r$ have decided to move from a cash accounting to an accrual accounting, the reform process is not yet completed everywhere (Ernst \& Young, 2012).

\section{Austria}

According to our survey, the Austrian central government uses in 2012, a modified accrual accounting (with the plan to adopt accrual accounting in 2013) while the level of local government is working with a modified cash accounting. These results are closely related to the study of Christiaens, Reyniers \& Rollé (2010). In 2007 and 2009, the Austrian Federal Parliament passed a major budget reform. The first stage of the reform, implemented in 2009, is the introduction of a medium-term framework for expenses and more flexibility for the Ministries. The second stage comes into force in 2013 and provides, moreover, the introduction of accrual accounting, applied to general accounting and to the budget (Steger, 2010). The federal government applies the Accounting Act of the State while Länder and municipalities must conform to the Regulation on Budget and Accounts.

\section{Belgium}

For the Belgian case, the accrual accounting is used, sometimes from a modified manner, by the Federal State, the Walloon, Flemish and Brussels-Capital regions, the French, Flemish and German communities, and locally (Note 5) by Brussels and Walloon entities. Local Flemish entities apply an accounting system in accordance with IPSAS and therefore based on the principles of accrual accounting. Originally limited to a cash budget accounting, the public accounting system has evolved and the various changes have led to an accounting system that is composed with two facets: budget accounting and general accounting, based on established entitlements, inspired from those that are applied within private companies. Local authorities were the first to implement such a system (in 1995 for the communities and in 1997 for PSAC and in 2003 for provinces). The Brussels-Capital reformed its accounting system in 2006 while the others are currently upgrading their accounting. The law of May 22, 2003 about the budgetary organization and the accounting of the Federal State introduces an accounting system that combines budgetary accounting and general accounting and based on the principle of established entitlement. At the entities' level, the law of May 16, 2003 also provides that communities and regions maintain a general accounting. Their implementation has been delayed several times and was finally set for January 1, 2012 (Note 6).

\section{Bulgaria}

According to our survey, Bulgaria applies a modified cash accounting at the central level government while a cash accounting is used at the local level. Bulgarian central government applies the requirements of the Accounting Law (Note 7) in budgetary and accounting terms. The reporting framework has been established based on:

- Requirements of the European Union in accounting, statistics and budgeting in the public sector;

- The accounting framework, principles and concepts from Handbook Government Finance Statistics issued by the IMF;

- International accounting standards for the public sector (IPSAS); and

- The requirements of the Bulgarian legislation regarding budgeting, execution and reporting of the Consolidated Budget Program, management and monitoring of revenues and expenses. (Hawkesworth, Emery, Wehner \& Saenger, 2009).

Furthermore, the accounts' structure and the rules and principles of accounting, evaluation and classification of assets, liabilities, revenues and expenses in the chart of accounts are, altogether, implemented in harmony with the ESA. In 
accordance with Bulgarian law of accounting and budget, budget units apply a unified chart of accounts (based on an accrual accounting for reports) and a unified budget classification (for reports on a cash basis). According to the organic law of the budget, monthly, quarterly and annual reports are established based on a cash accounting. The quarterly and annual financial reports are, as for them, prepared based on an accrual accounting, grouped and used for the ESA and the IMF for macroeconomic and fiscal analysis' purposes.

\section{Spain (Note 8)}

Spain uses a modified cash accounting at a local level as well as at a central level. As in most continental European countries, Spanish accounting standards are defined by law (Note 9). The current situation of public accounting in Spain is the result of reforms introduced since the late 70's, thanks to a change in policy after a long period of dictatorship.

The entry of Spain into the European Union has ensued the introduction of several reforms between 1986 and 1990. A new chart of accounts adapted to the EEC Fourth Directive has been introduced in 1990 for commercial entities. The new plan defines new accounting principles and new financial statements which inspired the chart of accounts' reform of 1981 and leads in 1994 to the introduction of a new chart of accounts for governmental entities (effective since January 1, 1995). The goal is to adapt the public sector accounting to accounting principles relevant to the private sector. This chart of accounts is still effective today in Spain; it shows the current reporting model of government accounting, defines the accounting principles for the budget and financial accounting as well as the form and the content of financial statements that are included in the annual accounts (Note 10). Thus, the legal framework for budgeting and accounting matter in Spain is very homogeneous. The Spanish municipalities' accounting system is very similar to the one adopted by the national government and the vast majority of regional governments (Note 11).

\section{Estonia}

According to our survey, Estonia uses accrual accounting at a central level as well as at a local level. Public sector accounting in Estonia is regulated by the Accounting Act (Law), where accounting principles are entirely based on an accrual accounting (central and local levels). Indeed, since its independence (1991), Estonia is in the forefront of institutional reform in the financial management matter. The revision of the organic budget Law (adopted in 1993) has led to the adoption of a new financial law introducing modern budgeting procedures based on transparency principles, budgetary discipline, effective parliamentary oversight and complete external audit (Kraan, Wehner \& Richter, 2008). Since 2004, a system of accrual accounting based on IPSAS standards is used in public administrations' sector. The system provides data on assets, liabilities, commitments and payments, and constitutes a sufficient basis for internal audit. The accounting data are presented to the Financial Control Department of the Ministry of Finance which is responsible for the publication and dissemination of financial statements. Moreover, the Ministry of Finance publishes monthly reports in a press release on the Internet. These reports follow the line-item budget to give a good overview of data on budget execution. Since 2000, Estonia has developed internal audit procedures in conformity with international standards, coordinated by the Ministry of Finance from its department. We can consider that Estonia has a fairly precise and consistent financial information system and in conformity with international standards of a financial matter.

\section{Finland}

The idea of an accrual accounting was introduced in 1988 in Finland (OECD, 2004) and according to Blöndal, Kristensen \& Ruffner (2002) the country is using this type of accounting to establish the annual accounts while the budget is based on a combination of systems of cash and accrual accounting. Our results show that Finland is currently working with a modified cash accounting at a local government level and with a modified accrual accounting in local entities. Vinnari \& Näsi (2008) also precise that the Finnish local governments in 1997 has adopted an accounting reform that led to the model of an accrual accounting, somehow different, on some aspects, from the one used in the private sector. However, our result for the central government is surprising since according to a recent source (Note 12), Finland is preparing its consolidated financial statements in accordance with the principles of accrual accounting. Ultimately, we can say that the Finnish authorities are in favor of a complete use of accrual accounting.

\section{France}

In France, the accounting system for central and local government entities is being held in established entitlements and therefore respects the principle of accrual accounting. Originally, the French government accounting system was a "cameral" system type, i.e. a cash accounting held "in a simple-entry bookkeeping". The introduction of a double-entry bookkeeping (general accounting) began in 1957 and the process was completed in 1960. The principle of cash accounting is, however, still applied. In 1999, the will to migrate to an accrual accounting system which is able to give 
a fair view of the assets, receivables and liabilities has been felt (Lande \& Scheid in Lüder \& Jones, 2003). In 2001, the organic law on finance laws (LOLF) was adopted. This law, which came into force completely in 2006, describes the principles regarding the content, the preparation, the adoption and the reporting of public accounts and aims, among others things, the implementation of an accrual accounting (art. 30) (OECD, 2004). Thus, the current French accounting system of public entities is similar to the one in force in the private sector with, nevertheless, some differences due to the characteristics of the public domain. For example, as emphasized by the respondent in our survey, "Some specifics related to the collection, including products related to income tax, tend to impose an accounting adapted to the timetable to know with certainty the basis of tax assessment. However, these constraints in timetable don't affect the quality of bookkeeping or their sincerity as attested by the renewed certification of the State accounts since 2006". We can note that the French State has adopted, in November 2012, a complete regulation on public budgetary and accounting management and on financial control within the State administrations (Decree No. 2012-1246 of November 7, 2012 on the public budgetary and accounting management). The decree emphasizes, among other things, the application of ESA standards, the use of budgetary accounting and a general accounting based on the established entitlements, control and internal audit.

\section{Greece}

The results of our survey show that Greece uses a modified cash accounting for the central level while local administrations are using an accrual accounting. Actually, there are six different systems of public accounting in Greece: the hospitals' one, the one of the social security funds, of municipalities, of public law corporations (including prefectures), of local authorities and of central government (Hawkesworth, Bergvall, Emery \& Wehner, 2008). The transition from a cash accounting to an accrual accounting is normally expected, but the authorities are being very cautious while moving in that direction. According to the comparative study of accounting systems used by European countries conducted by Ernst \& Young (2012), there are different laws that establish the central accounting procedure that has to be followed by the main public institutions (Ministries). However, different data can be provided and different methods can be used by the Ministries. Moreover, the latter have other legal public entities from their jurisdiction (hospitals, municipalities, etc.) for which there isn't a procedure. At the municipal level, there also isn't a common procedure or a unique model. The OECD has issued several recommendations regarding the improvement of public sector accounting in Greece. Although the accounts of the central government usually appear reliable, this is not the case for other parts of the public sector. The General Accounting Office (GAO) should standardize accounting systems in the public sector and impose standards for all entities (including at a local level).

\section{Hungary}

According to our survey, the Hungarian government accounting system is a "hybrid" one, essentially based on a cash accounting but using some elements related to an accrual accounting. The legal foundation of public accounting is given by the Public Finance Act of 1992 and by the Accounting Act of 2000, developed in a number of decrees and regulations (Kraan, Bergvall, Hawkesworth \& Krause, 2007). All central government entities follow the general accounting principles referring to the following decrees: the government decree 240/2003 (XII.17) on accounting specialties and on financial statements preparation of cash accounts for the b; the government decree 249/2000 (XII.24) on the accounting specialties and financial statements preparation of the government legal sector for budgetary central institutions, funds, the Government of National Minorities and the budgetary institutions' of national minorities; and the government decree 224/2000 (XII. 19) on accounting specialties and financial statements preparation of "other entities" as defined by the Accounting Act for public companies owned by the state.

As for the central government, the local governments apply the general principles of accounting and refer themselves to Decree 249/2000. The chart of accounts, the balance-sheet composition, and the requirements of financial information are also identified in the Government Decree (Ernst \& Young, 2012). All governmental units with legal personality and autonomous financial management disposal (including budgetary institutions, extra-budgetary and social security funds and local administrations) are reporting accounting entities and are required to have their own accounting in double parts. Accounting isn't centralized, which means that each budgetary institution makes its own accounting. However, in some regions, accounting is centralized (Ministry of Defense, of Police, some local governments) (Kraan et al., 2007). Each budgetary institution must respect the government accounting system. However, there isn't any accounting's software required and many different software are used by public entities (Ernst \& Young, 2012).

\section{Ireland (Note 13)}

The Irish public sector consists of the central government, extra-budgetary central government, local government and public enterprises. The Irish central government is currently using a system of a traditional accounting system based on 
a cash accounting. This system has been enhanced by a number of important reforms in recent years. Indeed, since the early of the 90's, it's its European integration and the recent financial crisis of 2008 that were the triggers for a significant improvement in budgetary transparency in Ireland. The main laws of the central government level are the Act entitled "Exchequer and Audit Department Act" of 1866 and the Act entitled "Comptroller and Auditor General Act" of 1993. Insofar as the central government accounting is mainly based on a cash accounting, the items recognized in the statement of financial situation are very limited. According to Ernst \& Young (2012), a reform to make the transition from a cash accounting to a complete accrual accounting is planned. Indeed, in 1999, a project (the "Management Information Framework") to develop a management and financial control framework for every single department capable of producing information on equalization accounts was launched and since the end of 2005, all Ministries have installed new financial (Note 14) information systems (Note 15). However, no precise timetable has been determined for the transition from a cash accounting to an accrual accounting.

The Irish local government respects the accounting rules established by the Code of Practice (Code in accounting practices' matter). The first code was made in 1998 but it changes over time as far as some accounting practices need to be developed. This code precises the principles and practices of accounting required to prepare annual financial statements. In 1996, new financial goals regarding the accounting of local authorities have been defined including the introduction of a complete (Note 16) accrual accounting. Since then, the Law of 2011 on Local Governments force local authorities to prepare their annual financial statements on the basis of an accrual accounting (Ernst \& Young, 2012).

\section{Italy}

In Italy, the central government is using the cash accounting and the accrual basis accounting, a method where revenues and expenses are registered when they are acquired (when the right to receive the money appears) or incurred (when the obligation to pay appears). Local governments also combine cash and accrual basis accounting systems. While budgets are based on accrual basis accounting, annual financial statements are established in accordance with the principles of cash and accrual basis accounting.

Traditionally, the budget and the financial statement (Note 17) (central level) are established according to the cash accounting and based on obligations (Note 18). It's a system of simple-entry bookkeeping that records financial transactions' movements. In 1997 (the Act of April 3, 1997, decree of August 7, 1997, or decree Lgs, 279/97), the idea to imbricate the accrual accounting to the traditional accounting system was introduced. Accounts' structure and the purpose of the book entries are specified but yet, no procedure is described, which makes the reform currently unfinished (Mussari, Grossi \& Castelnuovo in Lüder \& Jones, 2003). In 1995, a decree reforming local governments' accounting is adopted (Decree Dlgs 77/95) and encourages, among other things, the adoption of an accrual accounting (without making it mandatory) to complete the original accounting system based on the principles of cash and accrual basis. Indeed, so far, local government entities' accounting came down to a budgetary accounting whose main objective is to limit the expenses. However, the prescriptions of decree 77/95 remain very general and the budget and accounts of local administrations don't apply entirely accrual accounting yet. (Anessi-Pessina \& Steccolini 2007; Steccolini \& Caccia, 2006).

\section{Latvia}

The central government and the local administrations in Latvia apply the Law on budget and financial management as well as the government regulations on accounting referring to a modified accrual accounting in accordance with IPSAS standards. All public entities in Latvia therefore apply the same accounting standards, except public companies that apply the Law on financial statements in accordance with IFRS standards. The accounting system applied to financial statements is mainly based on an accrual accounting similar to IPSAS standards. According to our survey respondent, exceptions exist however regarding the registration of some transactions for which a modified accrual accounting basis is used. Those are transactions without compensation (taxes and transfers).

\section{Lithuania}

In Lithuania, central government and local administrations use an accrual accounting. Indeed, the reform that has been approved by the government in June 2005, introduced the transition from modified cash accounting to an accrual accounting for the Lithuanian public sector. The accounting legislation in Lithuania includes the Law on public accounting of June 26, which came into force on January 1, 2008 and the national standards for financial information established in accordance with IPSAS standards. According to Ernst \& Young (2012), there aren't different accounting practices between the levels of government. In conformity with laws, public institutions and local governments use since January 2010, an accrual accounting for the elaboration of their financial statements, established according to 
national standards for the financial reporting that are in conformity with IPSAS standards. However, the budget execution is still based on a cash accounting.

\section{Malta}

In the Republic of Malta, the central government is currently using a cash accounting including some elements of assets and liabilities (modified cash accounting). The Malta central government reporting system is described in the Law on financial administration and audit (Financial Administration and Audit Act) which lists the requirements for financial statement for each year. The Treasury Department of the Ministry of Finance began to prepare financial statements based on an accrual accounting from year 2002. However, it would seem that those financial statements are only meant for an internal use and therefore have never been published. There also isn't a legal obligation that requires preparing them. As for the local government, an accrual accounting that adheres to IFRS standards is currently used (Ernst \& Young, 2012).

\section{The Netherlands}

In the Netherlands, we can consider that the accounting system used at the central government is the modified cash accounting. Indeed, the system used at the central level can be qualified as an "integrated system of cash and commitments" since it consists of two systems: a first one based on the basis of commitments and a second one based on a cash accounting. In 1994, the creation of agencies, semi-independent public entities is the first step towards the accrual accounting. Those agencies must keep their accounts and their budget according to the principles of the accrual accounting. In 2000, the Ministry of Finance announced the government's intention to introduce the accrual accounting for the budget, in place of the existing cash accounting (Blöndal \& Kristensen, 2002; Bac in Lüder \& Jones, 2003). Currently, the accrual accounting is used by a significant part of the central government, agencies, autonomous administrative authorities and legal entities that perform legal tasks.

As for Dutch local entities, the accrual accounting appeared in 1979 for the provinces (with application for the accounting year of 1982) and in 1982 for municipalities (with application for the accounting year of 1985) (Bac in Lüder \& Jones, 2003). Accounting and budgetary standards that are currently applied came into force in 2004 and respect the principles of accrual accounting.

\section{Portugal}

The results of our study regarding Portugal show that the accounting systems used by governments are quite heterogeneous and sometimes combine the principles of cash accounting with accrual ones. The Portuguese government has introduced accrual accounting in 1997 but only just a few departments have implemented it. In 2008, the government has set up as a goal to use the principle of accrual accounting for the whole public administration and that, by the introduction of the software "Rede Integrada de Gestão e dos Recursos Orçamental do Estado" (rigore) (Curristine, Park \& Emery, 2008).

Currently, at the central and local levels, the accounting system in place is an integrated system composed by the budget, the financial statements and the management accounting in accordance with accrual accounting. This observation applies to local government (municipalities) and autonomous central government entities (universities, public institutions, hospitals, etc.). However, some instruments of the central government don't have the financial autonomy, such as ministerial offices and some governmental agencies that are still working only with a cash budget accounting.

With regard to other entities (including local government), the current system may be described as a hybrid system, combining the principles of the modified cash accounting for the budget (with the recognition of liabilities for expenses) with those of accrual accounting for the financial statements and management accounting (including the identification of the goods for the public matter and the allocation of functional costs, activities and projects (costs' centers)).

\section{Czech Republic}

According to our survey, the Czech Republic is currently applying an accrual accounting both at a central and at a local level. All central government entities apply the Accounting Act established in 1991 (amended in 2011), the Law on budgetary rules adopted in 2000 and finally, accounting decrees that is specific to different public sector units (for entrepreneurs, non-profit institutions, and special accounting units). These laws or rules refer to national standards based on IPSAS (except the Law on budgetary rules that refer only to national standards). Local government applies the same laws and rules as entities that compose the central government. However, other rules are also taken into account such as the accounting Decree for non-profit entities (2002) and accounting Decree for entrepreneurs in conformity with the Accounting Act. The reform of the accounting system of public finances, for the transition to the 
accrual accounting, was initiated in 2010 to the central government. The goal of this reform was to produce accurate and complete information regarding public finances of the country. The adoption of an accrual accounting for all government levels should be completed within two or three years, according to Ernst \& Young (2012) (Note 19).

\section{Romania}

Our survey reveals that the accounting system used by central and local government is the modified accrual accounting. It can't be qualified as a complete accrual accounting system because it lacks a series of elements required by this system. Indeed, all fixed assets are not depreciated, the depreciation of tangible assets is optional, the registration of provisions for receivables is optional and the obligations for pensions and other welfare benefits are not registered. The accounting rules are the same for all public institutions of central and local government and social security. All public institutions in Romania use a unique chart of accounts, a unique budgetary classification and a unique model for the presentation of financial statements.

Since the entry of Romania in the European Union, the public finances of the country are one of the top government priorities. The accounting in Romania is strongly guided by the directives and guidelines of the European Union. One of the critical objectives of the accounting reform in Romania, after its integration in the European Union, is comparability. The major event in the accounting matter is probably the government's decision, in 2002, to make the transition from a cash accounting to an accrual accounting and also the introduction of a new chart of accounts. Indeed, the introduction of an accrual accounting began in 2003 through several experimental projects to be generalized at a central government scale in 2005 (Ruffner, Wehner \& Witt, 2005). All Romanian public entities apply the same accounting laws: Law No. 82/1991 (Note 20) and the Minister of Finance's order No. 1917/2005 on specific methodological standards for the elaboration and presentation of public institutions' financial statements. The legislation currently into force doesn't foresee an accounting software that should be used by the different government levels. The systems that are used differ therefore at once vertically through the different power levels and horizontally between the different institutions present at the same level (Ernst \& Young, 2012).

\section{The United Kingdom}

According to our survey, the UK also uses the accrual accounting and that, within the central and local government. It's in 1995 that the British government began its accounting reform to establish a system based on accrual accounting (White Book "Resource Accounting and Budgeting in Government"). This reform aims a more effective management and an increased responsibility of Ministries. The accounting principles for the budget and the financial statements were then introduced into the "Government Resources and Accounts Act" (GRAA) of 2000 (OECD, 2004). Thus, in April 2001, the British government adopted an accounting system based on transactions (accrual accounting) (OECD, 2004). This reform, which puts to an end the principle of cash accounting, put the UK in a leading position regarding accounting reforms in the public sector (Scheers, Sterck \& Bouckaert, 2005).

\section{Slovakia}

According to our survey, the central government as well as the local government is currently using an accrual accounting. All entities composing the central government in Slovakia apply the Law No. 431/2002 Col. on accounting rules adopted by the Parliament in June 2002 (amended in 2010), the Law No. 523/2004 (amended in 2007) and the Law No. 502/2001 on the fiscal rules set by the Ministry of Finance. The laws into force at the local level include the Law No. 583/2004 regarding the budget and the accounting, the Law No. 431/2002 and fiscal rules. Since 2009, the Slovak public sector entities are required to establish verified consolidated financial statements in conformity with the accounting legislation (Law No. 431/2002, main accounting law in Slovakia. A unique and uniformed accounting information system doesn't exist but whatever the system used, it must meet the conditions defined by the law (Ernst \& Young, 2012). The central and local governments use the same regulatory structure for the elaboration of their financial declaration, of their chart of accounts and prepare consolidated financial statements. It exists still some differences between current Slovak accounting standards and IPSAS but the Ministry of Finance is working on it with the aim to make them disappear.

\section{Slovenia}

In 1999, a modernization process has led to the adoption of a new Accounting Act fore sighting the use of cash accounting for the Slovenian public sector and the introduction of a uniformed chart of accounts for all direct users of the budget (Kraan \& Wehner, 2005). The Slovenian Accounting Law sets out the accounting rules for any entity using public funds (from the state) without distinction between central and local government. According to our survey, at a central level, Slovenia is currently using a modified cash accounting based essentially on a cash accounting but comprising some elements related to an accrual accounting such as debit accounts and liabilities that are daily updated. 
For example, all liabilities are included in the users' accounts of the state budget (Note 21), but some receivables aren't included and are always kept out of these accounts. Local government applies the same laws for an accounting matter and is subject to the same audit as the central level. The accounting system used in Slovenia, the MFERAC, is a unified computerized accounting system for central government entities and a part of the municipalities. This is a planning resources' system that is daily updated (Ernst \& Young, 2012). Other municipalities, as pension and health funds have their own system. The annual financial statements are subjected to the Court of Auditors of the Republic of Slovenia (Court of Audit of the Republic of Slovenia).

\section{Sweden}

Sweden is currently using an accrual accounting in national government as well as in local government. The country meets indeed, the principles of accrual accounting in the central government since two decades. The system established is very influenced by the IPSAS and similar standards. This result is confirmed by the literature (Mattison, Paulsson \& Tagesson in Lüder \& Jones, 2003; European Commission, 2008).

At the central government level, the most financial, budgetary and accounting fundamental legal framework is set by the Government's Instrument (part of the Swedish Constitution). This fundamental law regulates the content of the State budget and the procedure thereto relative. Moreover, the Parliamentary Act (Riskdag Act) also regulates the finance, the budget and the accounting of the State, especially specifying the accounting information that the Government must provide to the Parliament. The Budget Act, dating back to 1996, regulates, among others things, questions related to accounting and auditing and is the result of the development of the State budgetary procedure. Finally, different orders, decrees and recommendations have seen the light of day. With regard to the local government, the financial, budgetary and accounting framework is set by the Municipal Act and the Accounting Act for municipalities, which came into force in 1998. Furthermore, various recommendations also exist. Several accounting and budgetary reforms were carried out in the central and local government in Sweden so that the systems that are currently in place are strongly close to the private sector accounting and respect completely the principles of accrual accounting. (Mattison et al. in Lüder \& Jones, 2003)

\section{Conclusion}

Our study reveals that the diversity of accounting systems can be observed between the different States but also within the country, from one entity to another (central-local). While some countries are actively seeking to modernize their accounting methods, others are still using more traditional accounting systems without showing any will of evolution. Thus, if some States such as Belgium, Estonia, France, Lithuania, Portugal, Romania, the United Kingdom, Slovakia and Sweden, are using an accrual accounting at all government levels, others are still working with a cash accounting, such as Italy for example.

Note that governments sometimes are using a combination of accounting systems, making the classification difficult in one or another category that we propose. It's the case for Belgium, Italy and Portugal for example.

In the literature, the accrual accounting usually appears as a key element of modern public management. Indeed, it allows to makes it possible to make the public authorities' accounts more transparent and to provide a more complete information, thus improving, among other things, decisions' making at a government level and make them more responsible.

But its usefulness within the public sector is sometimes questioned and, especially because of characteristics that are specific to this sector. Moreover, there is a disinterest for the accrual accounting in political discussions. The question then is to know whether the accrual accounting is really appropriate for public agencies whose activities are primarily for a social or a governmental purpose (Christiaens \& Rommel, 2008). According to the authors, the conceptual accounting framework for private companies is incompatible with activities that are characteristic to the public sector; those characteristics require information needs that sometimes diverge from accounting information that are needed within the private sector. However, we can claim that in European Union, the trend is the use of modern accounting systems based on accrual accounting. The benefits from this system appear to be relevant and have convinced many Member States. Further researches may investigate the implementation of this European accounting system a few years after the real implementation in order to test whether European countries are implementing the given accounting system in different paths. A second survey wave could also be implemented in order to evaluate the implementation of the International accounting standards for the public sector (IPSAS).

\section{References}

Amar, A., \& Berthier, L. (2008). Le Nouveau Management Public: Avantages et Limites. Revue RECEMAP, 1-13. 
Anessi-Pessina, E., \& Steccolini, I. (2007). Effects of Budgetary and Accruals Accounting Coexistence: Evidence from Italian Local Governments. Financial Accountability \& Management, 23(2), 113-131. http://dx.doi.org/10.1111/j.1468-0408.2007.00422.x

Bauman, B. (2008). La modernisation de la comptabilité publique. Les Cahiers des Sciences Administratives, 16, 1-99.

Blöndal, J. R., \& Kristensen, J. K. (2002). Budgeting in the Netherlands. OECD Journal on Budgeting, 1(3), 43-80. http://dx.doi.org/10.1787/16812336

Blöndal, J. R., Kristensen J. K., \& Ruffner, M. (2002). Budgeting in Finland. OECD Journal on Budgeting, 2(2), 119-152. http://dx.doi.org/10.1787/16812336

Caccia, L., \& Steccolini, I. (2006). Accounting change in Italian local governments: What's beyond managerial fashion?. Critical Perspectives on Accounting, 17(2-3), 154-174. http://dx.doi.org/10.1016/j.cpa.2003.05.004

Christiaens, J., \& Rommel, J. (2008). Accrual Accounting Reforms: Only for Business-like (parts of) Government. Financial Accountability \& Management, 24(1), 59-75. http://dx.doi.org/10.1111/j.1468-0408.2008.00443.x

Christiaens, J., Reyniers, B., \& Rolle, C. (2010). Les conséquences des IPSAS sur la réforme des systèmes d'information financière publique: étude comparative. Revue Internationale des Sciences administratives, 76(3), 563-581. http://dx.doi.org/10.3917/risa.763.0563

Circular 17/13: Requirements for Appropriation Accounts 2013, November 2013.

Curristine, T., Park, C-K.., \& Emery, R. (2008). Budgeting in Portugal. OECD Journal on Budgeting, 8(3), 1-60. http://dx.doi.org/10.1787/16812336

Directive 2011/85/EU of November 8, 2011 on requirements for budgetary frameworks of the Member States.

Ernst \& Young (2012). Overview and comparison of public accounting and auditing practices in the 27 EU Member States. P. 523.

European Commission. (2008). Modernisation du système comptable de l'UE. Une meilleure gestion de l'information et une transparence accrue. P. 12.

Groot, T., \& Budding, T. (2004). The influence of New Public Management practices on product costing and service pricing decisions in Dutch municipalities. Financial Accountability \& Management, 20(4), 421-443. http://dx.doi.org/10.1111/j.1468-0408.2004.00202.x

Hawkesworth, I., Bergvall, D., Emery, R., \& Wehner, L. (2008). Budgeting in Greece. OECD Journal on Budgeting, 2008(3), 1-50. http://dx.doi.org/10.1787/16812336

Hawkesworth, I., Emery, R., Wehner, L., \& Saenger, K. (2009). Budgeting in Bulgaria. OECD Journal on Budgeting, 2009(3), 133-183. http://dx.doi.org/10.1787/16812336

IFAC. (2003). Study 14: Transition to the Accrual Basis of Accounting: Guidance for Governments and Government Entities (Second Edition). Report of the Public Sector Committee.

Kraan D-J., Bergvall, D., Hawkesworth, I., \& Krause, P. (2007). Budgeting in Hungary. OECD Journal on Budgeting, 6(3), 1-61. http://dx.doi.org/10.1787/16812336

Kraan, D-J., \& Wehner, J. (2005). Budgeting in Slovenia. OECD Journal on Budgeting, 4(4), 55-98. http://dx.doi.org/10.1787/16812336

Kraan, D-J., Wehner, J., \& Richter, K. (2008). Budgeting in Estonia. OECD Journal on Budgeting, 8(2), 1-40. http://dx.doi.org/10.1787/16812336

Law of May 16, 2003 establishing general rules applicable to the budget, accountability controls and communities and regions accounting, and the organization of the control of the Court of Auditors, M.B. June 25, 2003.

Law of May 22, 2003 concerning organisation of the Federal government's budget and accounting system. M.B. July 3, 2003.

Local Authority accounting in Ireland. (2009). Code of Practice and Accounting Regulations. P. 63.

Lüder, K., \& Jones, R. (2003). Reforming Governmental Accounting and Budgeting in Europe. Fachverlag Moderne Wirtschafts, Frankfurt am Main, p. 1079.

OECD. (2002). Models of public budgeting and accounting reform. OECD Journal on Budgeting, 2(1), 1-354. 
OECD. (2004). The legal framework for budget systems. An international comparison. OECD Journal on Budgeting, $4(3), 1-479$.

Pina, V., \& Torres, L. (2003). Reshaping Public Sector Accounting: An International Comparative View. Canadian Journal of Administrative Sciences, 20(2), 334-350.

Ruffner, M., Wehner, J., \& Witt, M. (2005). Budgeting in Romania. OECD Journal on Budgeting, 4(4), 27-54. http://dx.doi.org/10.1787/16812336

Scheers, B., Sterck, M., \& Bouckaert, G. (2005). Lessons from Australian and British reforms in results-oriented financial management. OECD Journal on Budgeting, 5(2), 133-162. http://dx.doi.org/10.1787/16812336

Steger, G. (2010). Austria's budget reform: How to create consensus for a decisive change of fiscal rules. $O E C D$ Journal on Budgeting, 10(1), 1-14. http://dx.doi.org/10.1787/16812336

Torres, L. (2004). Accounting and Accountability: Recent Developments in Government Financial Information Systems. Public Administration and Development, 24(5), 447-456. http://dx.doi.org/10.1002/pad.332

Vinnari, E-M., \& Näsi, S. (2008). Creative Accrual Accounting in the Public Sector: «Milking» Water Utilities to Balance Municipal Budgets and Accounts. Financial Accountability \& Management, 24(2), 97-116. http://dx.doi.org/10.1111/j.1468-0408.2008.00448.x

\section{Notes}

Note 1. Lüder, in OECD (2002)

Note 2. Groot T. \& Budding T. (2008), « New Public Management's Current Issues and Future Prospects », Financial Accountability \& Management, Vol. 24, $\mathrm{n}^{\circ}$ 1, p. 1-13.

Note 3. IFAC (2003), «Study 14: Transition to the Accrual Basis of Accounting: Guidance for Governments and Government Entities (Second Edition) », Public Sector Committee.

Note 4. At a local level, each Lander has the ability to choose its own accounting system. The current Act provides that it can be either a cash or an accrual accounting.

Note 5. Local entities means provinces, municipalities and Public Social Assistance Centers (PSAC).

Note 6. Art. 133 provides that the Act come into foce on January 1, 2012. However, Art. 134, by way of derogation, provides the entry into force of the general part of the Act on January 1, 2009 for the FPS Chancellery, Budget, Personnel, Information and Communications Technology and Public Health; on January 1, 2010 for the FPS Employment, Social Security, Economy, Middle classes and Social integration; and on January 1, 2011 for the FPS Finance, Mobility, Foreign Affairs and Foreign Trade. Moreover, The Court of Auditors: Preparation of general government entities, administrative services with selfaccounting and state enterprises with accounting obligations of the Act of the Accounting of May 22, 2003; January 5, 2011.

Note 7. The Bulgarian Accounting Law was adopted on November 16, 2001 and entered into force January 1, 2002.

Note 8. Additional information are collected from Lüder \& Jones (2003).

Note 9. Accounting standards are always contained in any law, decree or order that is approved, respectively by the Parliament, the Government or the Ministry.

Note 10. The new Chart of Account of 1995 was extended to the regional level in 2001 and locally in 2003.

Note 11. At the regional level, the situation was different; regional governments have adopted their accounting system to the Chart of Account of 1994 at different times and this adaptation is very recent.

Note 12. Commission européenne (2008). «Modernisation du système comptable de l'UE. Une meilleure gestion de l'information et une transparence accrue», $12 \mathrm{p}$.

Note 13. Additional information collected for Ireland come from the Circular 17/13: Requirements for Appropriation Accounts 2013, November 2013.

Note 14. Local Authority accounting in Ireland, Code of Practice and Accounting Regulations, 31st December 2009, $63 \mathrm{p}$.

Note 15. Local Authority accounting in Ireland, Code of Practice and Accounting Regulations, 31st December 2009, $63 \mathrm{p}$. 
Note 16. Ibidem.

Note 17. The Annual General Account of the national government (Rendiconto generale dello Stato) includes the financial statement (Conto consuntivo ou Rendiconto finanziario) and the statement of assets and liabilites (Conto generale del Patrimonio ou Rendiconto patrimoniale), that shows the change in assets and liabilities and the situation at the end of the year.

Note 18. The recording of an expenditure is made when a legal obligation is incurred by the administration.

Note 19. This project is time consuming, requires the introduction of new software, methodological materials, etc.

Note 20. This law specifies the content of public accounting and designates the Ministry of Finance as a normative institution in terms of standards and regulations in the field of accounting.

Note 21. By State budget users, we mean the entities receiving money from the State. 